\title{
Effects of Wounding, Inoculum Density, and Biological Control Agents on Postharvest Brown Rot of Stone Fruits
}

\author{
Chuanxue Hong and Themis J. Michailides, University of California Davis, Department of Plant Pathology, \\ Kearney Agricultural Center, Parlier 93648; and Brent A. Holtz, University of California Cooperative Extension, \\ Madera 93637
}

\begin{abstract}
Hong, C. X., Michailides, T. J., and Holtz, B. A. 1998. Effects of wounding, inoculum density, and biological control agents on postharvest brown rot of stone fruits. Plant Dis. 82:1210-1216.

The effects of wounding, inoculum density, and three isolates (New, Ta291, and 23-E-6) of Trichoderma spp. and one isolate (BI-54) of Rhodotorula sp. on postharvest brown rot of stone fruits were determined at $20^{\circ} \mathrm{C}$ and $95 \%$ relative humidity (RH). Brown rot was observed frequently on wounded nectarine, peach, and plum fruits inoculated with two spores of Monilinia fructicola per wound, and occasionally on unwounded nectarine and peach fruits inoculated with the same spore load. Brown rot was observed on wounded plums only. A substantial increase in lesion diameter of brown rot was also recorded on wounded nectarines and peaches inoculated with suspensions of $\leq 20$ spores and $\leq 200$ spores per wound, respectively, compared with unwounded fruit. At concentrations of $10^{7}$ and $10^{8}$ spores per ml, all Trichoderma isolates substantially reduced brown rot on peaches (63 to 98\%) and plums (67 to 100\%) when fruits were inoculated with $M$. fructicola following the application of a biological control agent. Similarly, at $10^{8}$ spores per ml, the yeast BI-54 also suppressed brown rot on peaches completely and on plums by $54 \%$. Significant brown rot reduction was also achieved with the isolate New at a concentration of $10^{8}$ spores per ml, even when the biocontrol agent was applied $12 \mathrm{~h}$ after inoculation with M. fructicola and under continuous conditions of $95 \%$ RH. The isolates Ta291 and 23-E-6 also reduced brown rot significantly under drier (50\% RH) incubation conditions. These isolates provided the best control of brown rot on plums when they were applied 12 $\mathrm{h}$ earlier than inoculation with $M$. fructicola. Satisfactory control of brown rot on plums inoculated with $M$. fructicola at $8 \times 10^{4}$ spores per $\mathrm{ml}$ was achieved with New at $10^{6}$ spores per $\mathrm{ml}$ and with Ta291 at $10^{7}$ spores per ml. Measures taken to avoid injuring fruit will greatly reduce brown rot of stone fruit at any spore load for plum, but only at $\leq 50$ spores per $\mathrm{mm}^{2}$ for peach, and at $\leq 5$ spores per $\mathrm{mm}^{2}$ for nectarine. This study identifies two isolates (Ta291 and New) of Trichoderma atroviride, one isolate (23-E-6) of T. viride, and one of Rhodotorula sp. that show potential for further development as biocontrol agents of postharvest brown rot of stone fruits.
\end{abstract}

Additional keywords: incubation period, infection efficiency, Prunus

Brown rot, caused by Monilinia fructicola (G. Wint.) Honey, is one of the most destructive diseases of stone fruits $(7,20,32)$. This disease starts with blossom blight, then progresses into a twig blight and canker, which can provide inoculum for latent infection of green fruit. From these latent infections, fruit brown rot develops prior to harvest and during storage and transport to market. Sometimes brown rot even affects the fruit at the processing stage and the processed product (3). In California, blossom blight and preharvest fruit brown rot may differ greatly from season to season, mainly depending on weather conditions (32). In contrast, a

Corresponding authors: C. X. Hong

and T. J. Michailides

E-mails: chuanxue@uckac.edu

and themis@uckac.edu

Accepted for publication 23 July 1998.

Publication no. D-1998-0824-01R

(C) 1998 The American Phytopathological Society decay of $>50 \%$ of fruit caused by $M$. fructicola at the postharvest stage is common, regardless of the incidence of preharvest brown rot (44).

A number of factors affecting decay of stone fruit by $M$. fructicola have been studied separately. The higher the inoculum concentration, the more severe and rapid the decay that developed on unwounded peach and cherry fruits (34). Wounds, including bruising, also greatly facilitated decay of apricot (47), peach (20), and plum fruits (46).

Two approaches have been employed to control postharvest brown rot in California. One approach has been the preharvest application of fungicides to prevent the activation of latent infection and/or to protect fruits from further infections (44). The success of this strategy depends largely on the prediction of latent infections. The other approach has been the use of postharvest treatments, primarily with fungicides. Before 1996, fungicides such as benomyl, iprodione, and triforine were registered for postharvest treatment of stone fruits to control brown rot $(11,44)$ Because of fungicide resistance, benomyl can no longer be used, and iprodione was voluntarily canceled by Rhône-Poulenc Ag. Co. in 1996 (1). Since then, the stone fruit industry has had no fungicide registered for control of postharvest brown rot.

Emerging alternatives to the chemical control of postharvest decay of stone fruits include (i) a treatment with hot water mixed with $10 \%$ alcohol (25); (ii) fumigation with carbon dioxide (7), acetic acid (42), and other volatile compounds from peach fruit (18); (iii) plant hormesis induced by ultraviolet light (45); (iv) use of the toxicity of calcium salts (2) and sugar analogs (9); (v) biological control $(10,17,43,44)$; and (vi) combinations of the above (11). Some of these alternative measures, such as biological control, provide great promise for future management of postharvest brown rot and have been investigated intensively.

An isolate of Bacillus subtilis partially controlled postharvest peach brown rot experimentally $(13,26)$ and on commercial packing lines $(39,40)$. Pseudomonas corrugata and $P$. cepacia also substantially reduced the decay of artificially wounded and inoculated nectarines and peaches (44), and improved peach puree quality (3). Furthermore, some yeasts either reduced brown rot incidence (44) or decreased lesion diameter (27). However, the efficacy of Trichoderma spp., one of the most widely demonstrated and used biological agents for control of plant diseases $(8,35)$, has not been documented against $M$. fructicola.

The purpose for the present research was to expand the search for potential biological agents after the cancellation of the registration of iprodione for postharvest brown rot control. The specific objectives of this research were to determine (i) the effects of wounding and inoculum density on brown rot of nectarine, peach, and plum fruits; and (ii) the effectiveness of biological control agents against brown rot of peach and plum fruits.

\section{MATERIALS AND METHODS}

Effects of wounding and inoculum density of $M$. fructicola on infection of nectarine, peach, and plum fruits. Mature fruits of peach (Prunus persica (L.) Batsch. cv. Elegant Lady), nectarine ( $P$. persica var. nectarina (Ait.) Maxim. cv. 
Fantasia), and plum (P. salicina Lindl. cv. Casselman) were hand-picked from experimental orchards at Kearney Agricultural Center, Parlier, California, during commercial harvest and kept in a cold room at $0.5^{\circ} \mathrm{C}$ until used (up to 3 weeks). Fruit were surface disinfested by immersing them in a solution containing $160 \mathrm{ml}$ of ethyl alcohol and $160 \mathrm{ml}$ of chlorine $(\mathrm{NaOCl})$ plus $0.5 \mathrm{ml}$ of Tween 20 in 10 liters of water for $4 \mathrm{~min}$, and allowed to air-dry on a laboratory bench. Disinfested fruits were placed on plastic holders (one layer) in commercial cardboard boxes with their equatorial part facing uppermost and were preconditioned for 3 to $6 \mathrm{~h}$ prior to inoculation with $M$. fructicola in a walk-in chamber at $20^{\circ} \mathrm{C}$ and $95 \%$ relative humidity (RH).

M. fructicola isolate 5-E-3 was isolated from a nectarine fruit and used throughout this study. The isolate was cultured in petri dishes containing acidified $(2.5 \mathrm{ml}$ of a $25 \%[\mathrm{vol} / \mathrm{vol}]$ lactic acid per liter of medium) potato dextrose agar. Inoculum of M. fructicola was prepared by flooding the surface of a 9-day-old culture, blending the suspension for $1 \mathrm{~min}$, then filtering through eight layers of cheesecloth. The concentration of M. fructicola was measured with a hemacytometer and diluted to $10^{6}, 10^{5}, 10^{4}$, $10^{3}$, and $10^{2}$ spores per $\mathrm{ml}$.

Fruits were separated into two batches. In the first batch, one wound ( $2 \mathrm{~mm}$ deep and $2 \mathrm{~mm}$ wide) was made on the equator (top) of each fruit with a sterile nail. Twenty microliters of a suspension of $M$. fructicola was applied to the wound of each wounded fruit and at the same position on unwounded fruits. The test was done twice with three replicates per treatment and five to eight fruit per replicate. After inoculation, fruits were kept in the same chamber for $24 \mathrm{~h}$ to ensure about 12 $h$ wetness on the inoculation sites of unwounded fruit, and then moved to a reachin chamber also kept at $20^{\circ} \mathrm{C}$ but $50 \% \mathrm{RH}$ for 5 to 7 days.

Incubated fruits were examined daily for 6 to 8 days after inoculation for brown rot development by measuring lesion diameter for nectarines and peaches and by rating severity for infected plums. The severity rating scale of infected plums was: 0 , no symptoms; 1 , the area exhibiting sporulation of $M$. fructicola restricted to $<2 \mathrm{~cm}$ in diameter around the wound; 2, the area of sporulation extending beyond $2 \mathrm{~cm}$ in diameter but still covering a small portion of fruit surface (top half); and 3, sporulation covering the majority of the fruit surface. Daily brown rot severity was calculated for each replicate in all tests and subjected to analysis of variance using Proc. GLM of the SAS package (Version 6.12, SAS Institute, Cary, NC). The brown rot severity read 6 days after inoculation was further regressed against the logarithmic transformed inoculum density. The incidence of brown rot was summarized by fruit variety at the inoculum density of two spores per wound or fruit to give indications of infection efficiency of $M$. fructicola on wounded and unwounded fruits. Lesions that did not originate from the inoculation points were considered natural infections. These were recorded separately and excluded from the calculations and statistical analysis of deliberate inoculations.

Efficacy of biological control agents against brown rot of peach and plum fruits. Four biological control agents at two concentrations plus one positive control (using $20 \mu \mathrm{l}$ of sterile deionized water [SDW], then $20 \mu \mathrm{l}$ of a suspension of $M$. fructicola) were included in the test. The test was repeated at least once on individ-
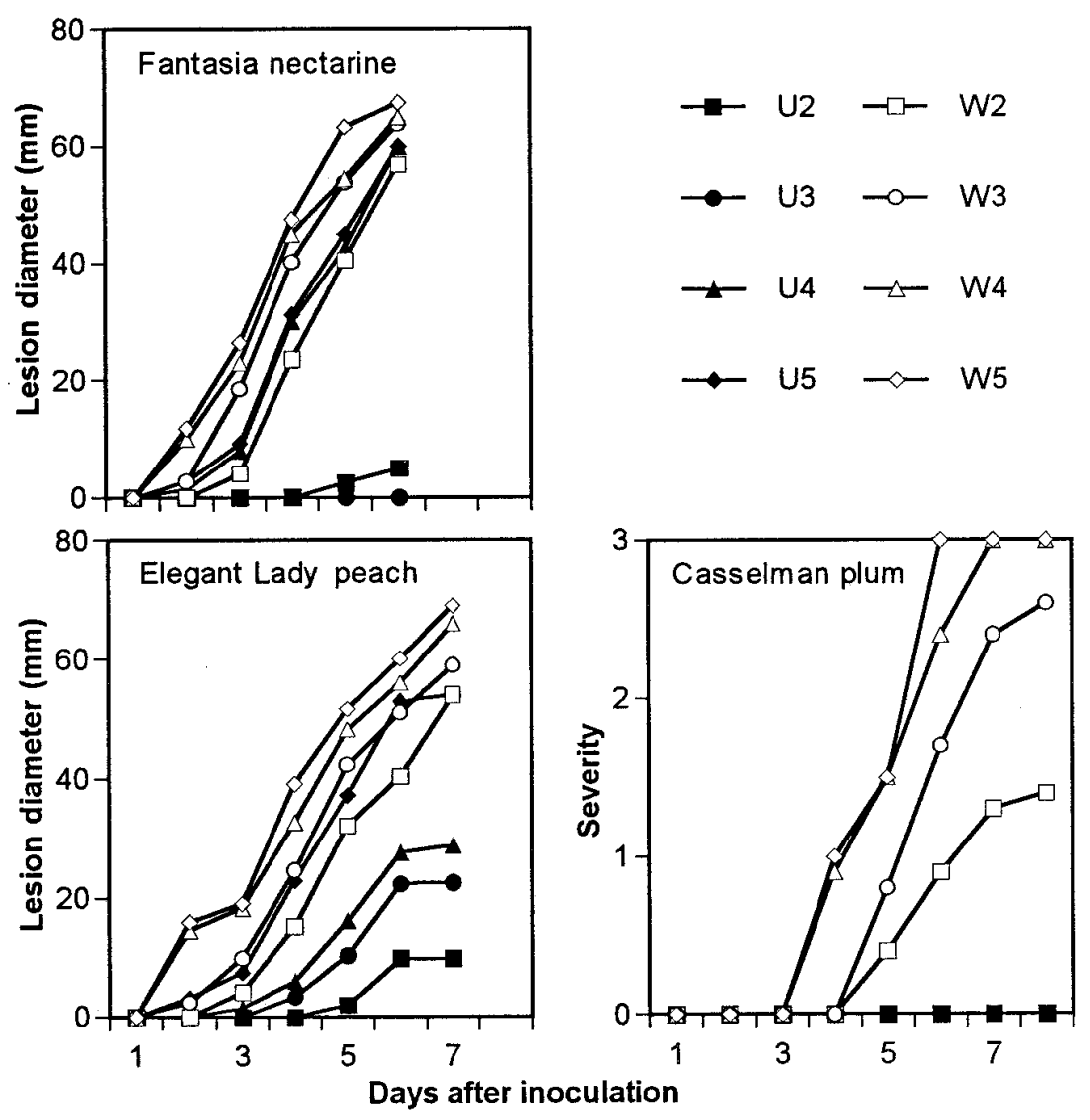

Fig. 1. Brown rot development on wounded (W) and unwounded (U) nectarine (cv. Fantasia), peach (cv. Elegant Lady), and plum (cv. Casselman) fruits inoculated with $20 \mu 1$ of a suspension containing $10^{2}(2), 10^{3}(3), 10^{4}(4)$, or $10^{5}(5)$ spores of Monilinia fructicola per ml. Fruit were incubated at $20^{\circ} \mathrm{C}$ and $95 \%$ relative humidity $(\mathrm{RH})$ for $24 \mathrm{~h}$, then at $20^{\circ} \mathrm{C}$ and $50 \% \mathrm{RH}$ for the remainder of the incubation period.

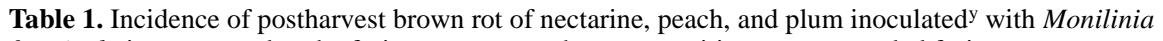
fructicola into a wound at the fruit equator or at the same position on unwounded fruit

\begin{tabular}{llccccc} 
& & \multicolumn{2}{c}{ Infected fruit $(\boldsymbol{\%})$} & & \multicolumn{2}{c}{ Putative infection efficiency $\mathbf{z}^{\mathbf{z}}$} \\
Fruit & Cultivar & Wounded & Unwounded & & Wounded & Unwounded \\
\hline Nectarine & Fantasia & 100 & 25 & & 0.50 & 0.13 \\
Peach & Elegant Lady & 100 & 30 & & 0.50 & 0.15 \\
Plum & Casselman & 54 & 0 & & 0.27 & 0 \\
\hline
\end{tabular}

y Two spores were applied per wound in each fruit. Fruit were incubated at $20^{\circ} \mathrm{C}$ and $95 \%$ relative humidity (RH) for $24 \mathrm{~h}$, then at $20^{\circ} \mathrm{C}$ and $50 \% \mathrm{RH}$ for an additional 5 days.

${ }^{\mathrm{z}}$ Infection efficiency was calculated by dividing the proportion of infected fruit by 2 (number of spores applied in each drop to each fruit). ual varieties of two peaches and one plum, three to six replicate boxes and five to lates Ta291 and New of Trichoderma atroviride Karsten were isolated originally from green grapes, respectively, and isolate 6 of Trichoderma viride Pers. ex S. The yeast (Rhodotorula sp.) isolate BI-54 ratory, Fresno. The biological control and suspensions of $10^{7}$ and $10^{8}$ spores per $\mathrm{ml}$ were prepared. In addition, a $10^{3}$ ARS Horticultural Cr. Smilanick, USDApotato dextrose agar plates for 9 days, 

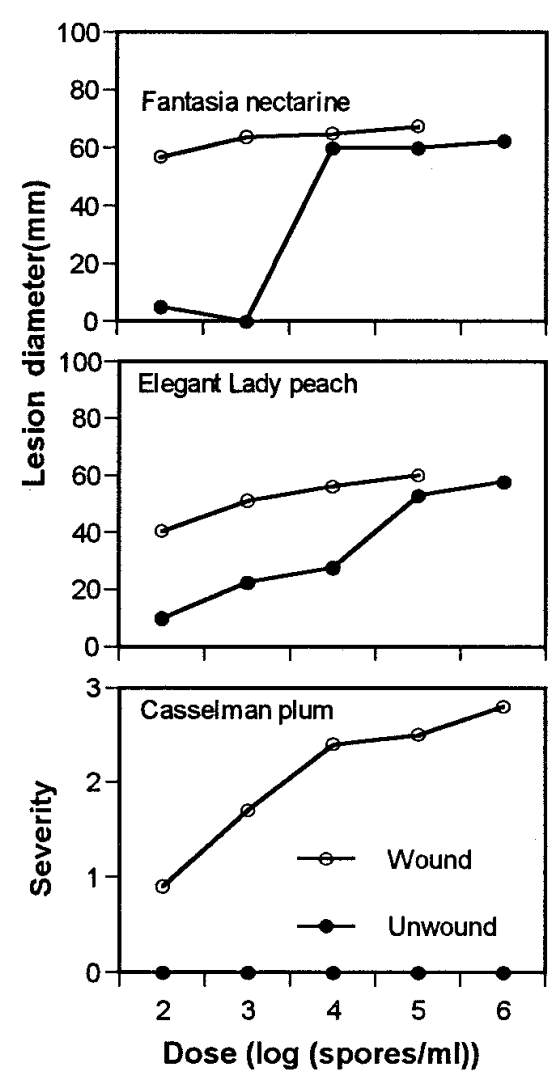

Fig. 2. Comparison of brown rot development between wounded (W) and unwounded (U) nectarine (cv. Fantasia), peach (cv. Elegant Lady), and plum (cv. Casselman) fruits inoculated with $20 \mu \mathrm{l}$ of a suspension containing $10^{2}$, $10^{3}, 10^{4}, 10^{5}$, or $10^{6}$ spores of Monilinia fructicola per $\mathrm{ml}$ and incubated at $20^{\circ} \mathrm{C}$ and $95 \%$ relative humidity (RH) for $24 \mathrm{~h}$, then at $20^{\circ} \mathrm{C}$ and $50 \%$ RH for an additional 5 days. spores per ml suspension of $M$. fructicola was prepared.

Peach (cvs. Elegant Lady and Fairtime) and plum (cv. Casselman) fruits were picked, surface-disinfested, and preconditioned as previously described. One wound was made on the equator of each plum with the sterile nail, but peaches were not wounded prior to the application of biological control agents. Twenty microliters of a suspension of $M$. fructicola was applied at each wound site for plums and at the same position on peaches immediately following the application of $20 \mu \mathrm{l}$ of biological control agent. Fruits were incubated for 6 to 10 days and examined daily for brown rot development as described previously. The incidence and severity of brown rot were calculated and analyzed as described above.

Timing of application of biological control agents to suppress brown rot of plums. Two or three timings of four isolates at two concentrations plus one positive control and one negative control (using SDW) were included in the test. The test was repeated twice, with three replicates per treatment and eight plums per replicate in each test. Plums (cv. Casselman) were harvested and surface disinfested, and inocula of M. fructicola and biological control agents were prepared as previously described. In the first two tests, three control agent timings were used relative to the time of application of $20 \mu \mathrm{l}$ of $M$. fructicola. An aliquot of $20 \mu \mathrm{l}$ of biological control agent was applied $12 \mathrm{~h}$ prior to pathogen application, immediately following the pathogen, or $12 \mathrm{~h}$ after the pathogen. For the first test, the concentration of suspension was $10^{3}$ spores of $M$. fructicola per $\mathrm{ml}$; fruit were kept in a walk-in chamber $\left(20^{\circ} \mathrm{C}\right.$ and $\left.95 \% \mathrm{RH}\right)$ for $24 \mathrm{~h}$ after the challenge inoculation was made, then moved to a reach-in chamber $\left(20^{\circ} \mathrm{C}\right.$ and $50 \% \mathrm{RH})$ and incubated for an additional 6 days. For the second test, the concentration of $M$. fructicola was $4 \times 10^{4}$ spores per $\mathrm{ml}$; fruit were incubated at $20^{\circ} \mathrm{C}$ and $95 \% \mathrm{RH}$ until the end of the test ( 7 days). In the third test, only two timings were employed; fruits were inoculated with $M$. fructicola at $10^{3}$ spores per $\mathrm{ml}$, and the biological control agents were applied either $12 \mathrm{~h}$ earlier or $12 \mathrm{~h}$ later than the inoculation. Fruit were rated, and the incidence and severity of brown rot were calculated and analyzed as described previously.

Effect of concentrations of biological control agents on postharvest brown rot of plums. Plums (cv. Casselman) were harvested and surface disinfested as previously described. Three Trichoderma isolates (Ta291, 23-E-6, and New) at concentrations of $4 \times 10^{4}, 4 \times 10^{5}, 4 \times 10^{6}, 4 \times$ $10^{7}$, and $4 \times 10^{8}$ spores per $\mathrm{ml}$ were included in the test. All inocula were prepared from 9-day-old cultures. Fruit wounds were inoculated with $M$. fructicola using $8 \times 10^{4}$ spores per $\mathrm{ml}$ immediately following the application of individual biological control agents. The test included three controls: positive applied with SDW/5E-3, negative with SDW/nil, and the third with nil/nil on wounds. There were three replicates per treatment and eight plums per replicate in each of the two tests. Fruits were incubated for 7 days at $20^{\circ} \mathrm{C}$ and $95 \% \mathrm{RH}$, then rated. The incidence and severity of brown rot were calculated and analyzed as previously described.

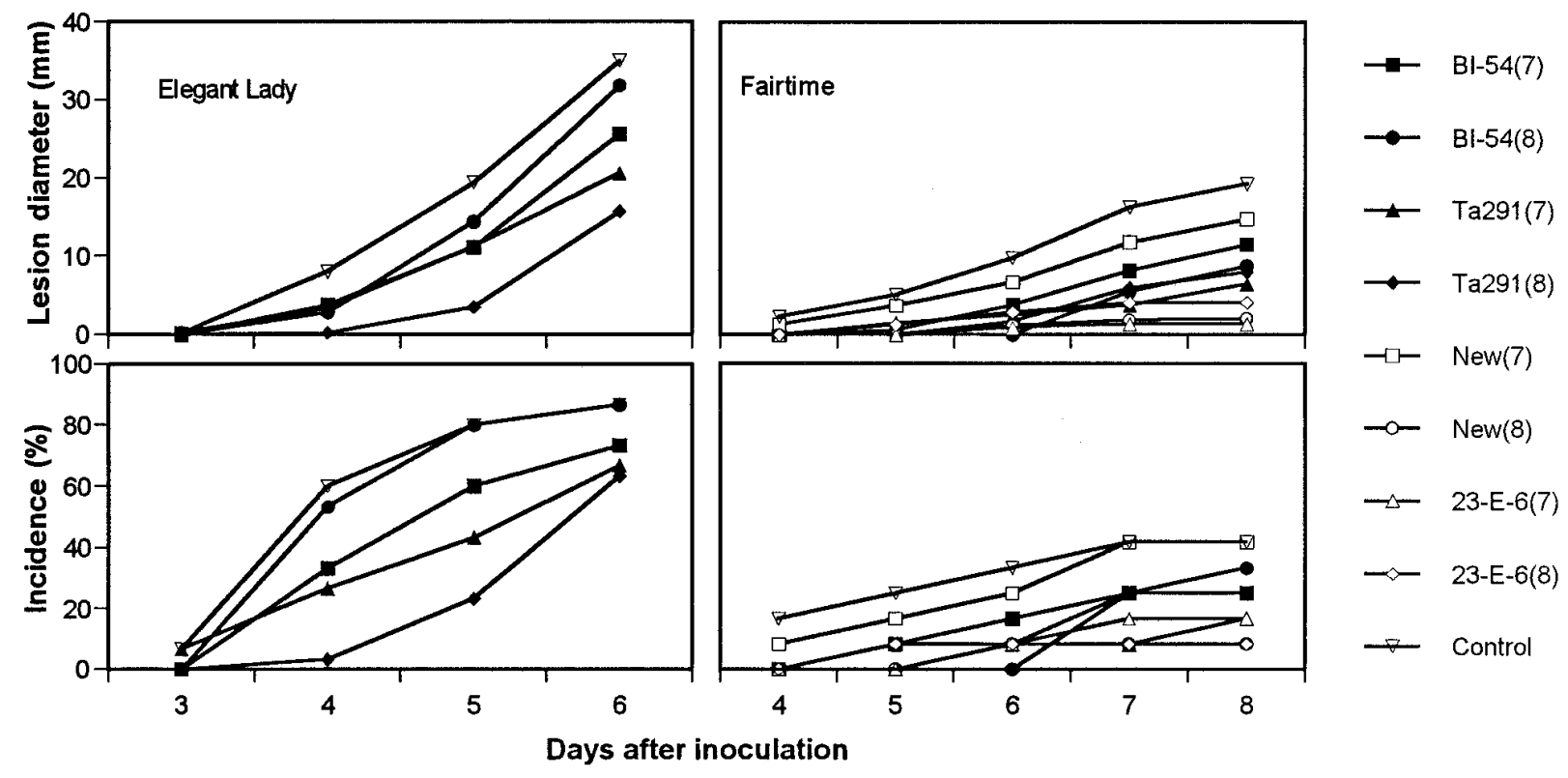

Fig. 3. Brown rot development on unwounded peaches (cvs. Elegant Lady and Fairtime) inoculated with $20 \mu 1$ of a suspension containing $10^{3}$ spores of Monilinia fructicola per ml immediately following the application of $20 \mu \mathrm{l}$ of biological control agent, incubated at $20^{\circ} \mathrm{C}$ and $95 \%$ relative humidity (RH) for $24 \mathrm{~h}$, then at $20^{\circ} \mathrm{C}$ and $50 \% \mathrm{RH}$ for the remainder of the incubation period. Number in parentheses following the isolate name represents the concentration applied, e.g., BI-54(7) denotes that BI-54 was applied at $10^{7}$ spores per $\mathrm{ml}$. 


\section{RESULTS}

Effects of wounding and inoculum concentration of $M$. fructicola on infection of nectarine, peach, and plum fruits. Brown rot was first observed on nectarine and peach fruits 2 days and on plums 4 days after inoculation (Fig. 1). The disease severity (or lesion diameter) increased as the incubation progressed up to 6 days postinoculation, depending on the wounding and inoculum density (Fig. 1). Approximately $2 \%$ of fruits were naturally infected and developed brown rot symptoms during incubation. Symptoms resulting from natural infections were easily recognized by their distance from the inoculation points and by the time of their appearance. They usually developed more slowly than those resulting from artificial inoculation with high conidial concentrations. Brown rot was observed frequently on wounded nectarine, peach, and plum fruits inoculated with $M$. fructicola at a concentration of two spores per wound (20 $\mu \mathrm{l}$ of $10^{2}$ conidia per $\mathrm{ml}$ ) and occasionally on unwounded nectarine and peach fruits at the same spore load (Table 1, Figs. 1 and 2).

Wounds greatly facilitated the infection of all fruits by M. fructicola at all concentrations tested (Figs. 1 and 2). Brown rot was observed only on wounded but not on unwounded plums, even at the highest inoculum concentration of $10^{6}$ spores per $\mathrm{ml}$ (Fig. 2). A substantial increase in lesion diameter and daily growth rate was also observed on wounded nectarines inoculated with the suspensions of $\leq 10^{3}$ spores per $\mathrm{ml}$ and peaches with suspensions of $\leq 10^{4}$ spores per $\mathrm{ml}$, compared with unwounded fruit (Figs. 1 and 2). In general, the severity of brown rot increased in a sigmoidal pattern on all wounded fruits and unwounded nectarine and peach fruits as inoculum density increased (Fig. 2).

Efficacy of biological control agents against brown rot of peach and plum fruits. Brown rot symptoms were observed 3 days after the inoculation of control Elegant Lady peaches and 4 days on Fairtime peaches. The diameter of brown rot lesions was significantly $(P=0.003)$ reduced on Elegant Lady peaches protected with BI-54 or Ta291 at either concentration of $10^{7}$ and $10^{8}$ spores per $\mathrm{ml} 4$ days after inoculation (Fig. 3). Significant reduction of brown rot severity was achieved with Ta291 but not with BI-54 6 days postinoculation (Fig. 3). Reduction of brown rot severity was achieved on Fairtime peaches with four biological control agents only at the concentration of $10^{8}$ spores per $\mathrm{ml} 5$ days after inoculation (Fig. 3).

Brown rot was observed 5 days after inoculation with $M$. fructicola on control plums, and 1,2, and 6 days later on plums protected with BI-54 and 23-E-6, Ta291, and New, respectively (Fig. 4). Brown rot was suppressed greatly $(P<0.001)$ on plums protected with all biological control

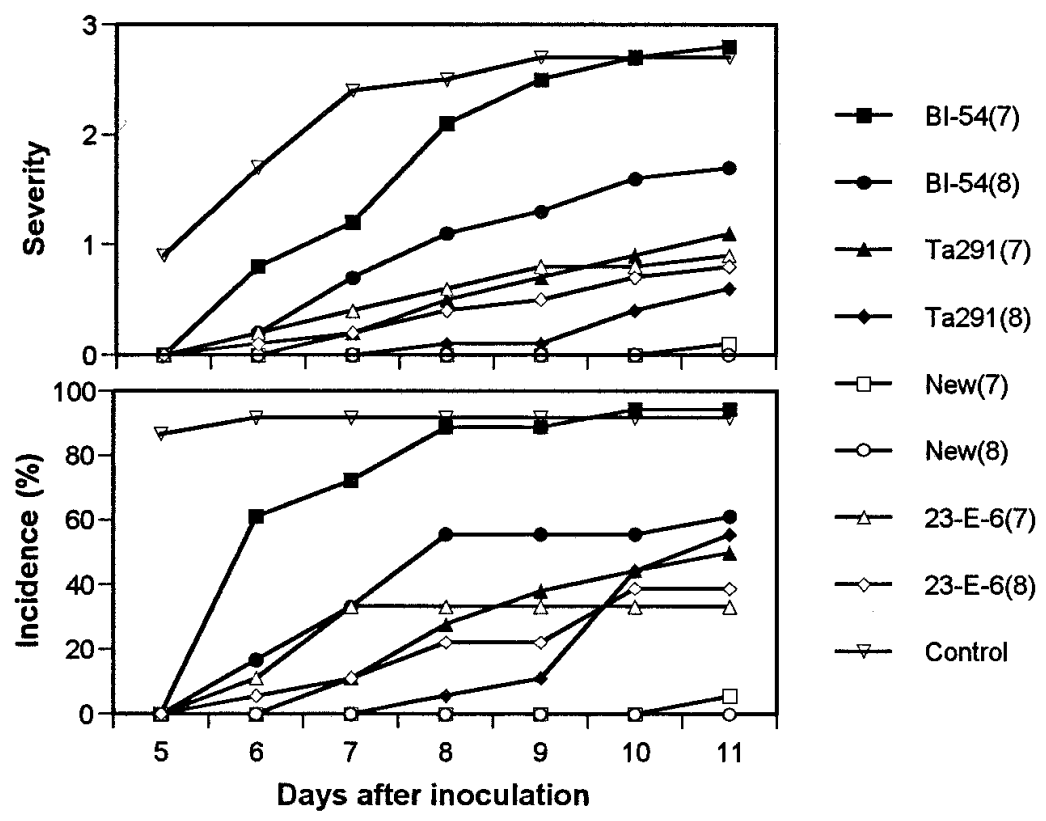

Fig. 4. Brown rot development on wounded plums (cv. Casselman) inoculated with $20 \mu$ of a suspension containing $10^{3}$ spores of Monilinia fructicola per $\mathrm{ml}$ immediately following the application of $20 \mu \mathrm{l}$ of biological control agent, incubated at $20^{\circ} \mathrm{C}$ and $95 \%$ relative humidity (RH) for $24 \mathrm{~h}$, then at $20^{\circ} \mathrm{C}$ and $50 \% \mathrm{RH}$ for the remainder of the incubation period. Number in parentheses following the isolate name represents the concentration applied, e.g., BI-54(7) denotes that BI-54 was applied at $10^{7}$ spores per ml.
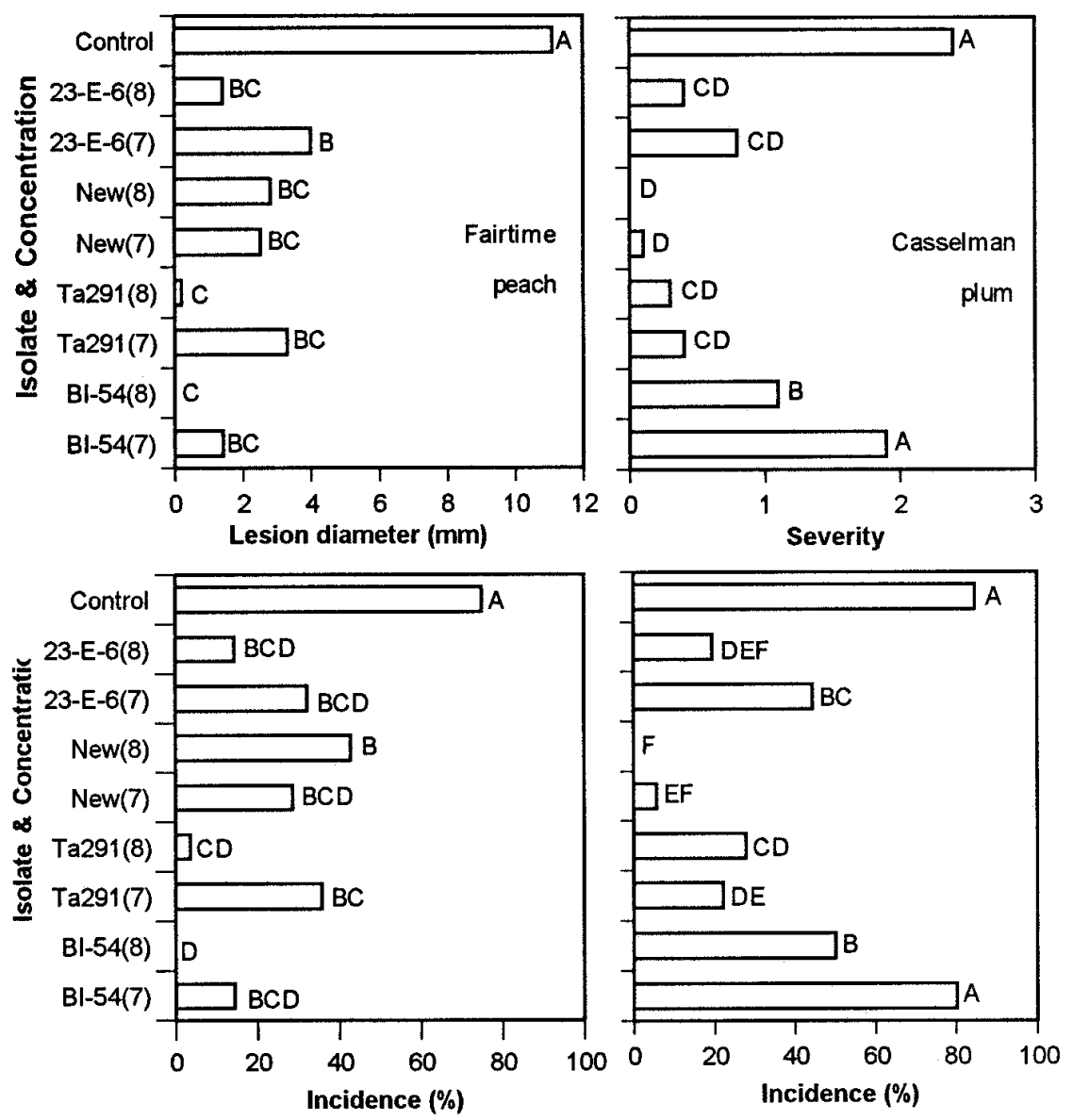

Fig. 5. Effects of biological agent and inoculum concentration on the severity and incidence of brown rot of unwounded peach (cv. Fairtime) and wounded plum (cv. Casselman) fruits inoculated with $20 \mu \mathrm{l}$ of a suspension containing $10^{3}$ spores of Monilinia fructicola per ml immediately following the application of 20 $\mu \mathrm{l}$ of each biological control agent, incubated at $20^{\circ} \mathrm{C}$ and $95 \%$ relative humidity (RH) for $24 \mathrm{~h}$, then at $20^{\circ} \mathrm{C}$ and 50\% RH for 3 and 6 days, respectively. Number in parentheses following the isolate name represents the concentration, e.g., BI-54(7) denotes that BI-54 was applied at $10^{7}$ spores per ml. Mean bars topped with different letters differed significantly according to Fisher's least significant difference $(P=0.01)$. 
agents at both concentrations throughout the tests (11 days) except for BI-54 at $10^{7}$ spores per ml (only 7days) (Fig. 4).

Trichoderma isolates reduced the severity of peach brown rot by 63 to $98 \%$; BI-54 reduced decay by $100 \%$ at a concentration of $10^{8}$ spores per $\mathrm{ml}$ and $87 \%$ at $10^{7}$ spores per ml (Fig. 5). Isolates Ta291 and BI-54 gave discernibly better control of brown rot on peaches than did the other isolates at $10^{8}$ spores per ml (Fig. 5). However, the three Trichoderma isolates gave better control of brown rot on plums than did the yeast isolate BI-54 at comparable concentrations (Fig. 5). The isolate New gave discernibly better control of brown rot than did the other two Trichoderma isolates on plums. BI-54 reduced brown rot of plums only at $10^{8}$ spores per $\mathrm{ml}$ but not at $10^{7}$ spores per ml (Fig. 5).

Timing of application of biological control agents against brown rot of plums. All biocontrol agent isolates tested gave the best control of brown rot on plums when they were applied to wounds $12 \mathrm{~h}$ earlier than the inoculation with $M$. fructicola (Fig. 6). The yeast isolate BI-54 suppressed brown rot only when it was applied $12 \mathrm{~h}$ earlier than the challenge inoculation and only in the first test but not in the second, a more critical test conducted under continuously high humidity. In contrast, at a concentration of $10^{8}$ spores per $\mathrm{ml}$, the isolate New significantly suppressed brown rot even when it was applied to the wounds $12 \mathrm{~h}$ later than the inoculation with $M$. fructicola in these tests (Table 2). Similarly, at a concentration of $10^{8}$ spores per $\mathrm{ml}$, the other two Trichoderma isolates (Ta291 and 23-E-6) also suppressed brown rot substantially, even when they were applied $12 \mathrm{~h}$ later than the inoculation with $M$. fructicola during the first test. Similar data were obtained from the third experiment (data not shown).

Effect of concentration of biological control agent on postharvest brown rot of plums. The incidence of brown rot decreased as the concentration of biological control agent (New or Ta291) increased (Fig. 7). On plums, satisfactory control was achieved with isolate New at $10^{6}$ spores per $\mathrm{ml}$, and with isolate Ta291 at $10^{7}$ spores per $\mathrm{ml}$, but not with isolate 23 E-6 at any concentrations tested.

\section{DISCUSSION}

Effects of wounding or inoculum concentration on decay of stone fruits by $M$. fructicola have been investigated previously $(20,34,37,46)$. This study further provides quantitative information on the effects of interaction between wounding and inoculum concentration on postharvest brown rot of nectarine, peach, and plum. Brown rot was not observed on any unwounded plums inoculated with $M$. fructicola at concentrations from $10^{2}$ to $10^{6}$ spores per $\mathrm{ml}$. This result is consistent with a previous observation (46). The signifi-
Table 2. Biocontrol of postharvest brown rot of plums (cv. Casselman), caused by Monilinia fructicola, at different timings of application of biological agents ${ }^{\mathrm{y}}$

\begin{tabular}{lcccc}
\hline $\begin{array}{l}\text { Biological } \\
\text { agent }\end{array}$ & $\begin{array}{c}\text { Concentration } \\
\text { (spores/ml) }\end{array}$ & \multicolumn{3}{c}{ Control (\%) } \\
\cline { 3 - 5 } & $10^{8}$ & $100 \mathrm{a}^{\mathrm{z}}$ & Simultaneous & 12 h later \\
\hline New & $10^{7}$ & $100 \mathrm{a}$ & $100 \mathrm{a}$ & $91 \mathrm{a}$ \\
& $10^{8}$ & $93 \mathrm{a}$ & $98 \mathrm{a}$ & $19 \mathrm{bc}$ \\
Ta291 & $10^{7}$ & $100 \mathrm{a}$ & $76 \mathrm{a}$ & $36 \mathrm{~b}$ \\
& $10^{8}$ & $100 \mathrm{a}$ & $69 \mathrm{a}$ & $-1 \mathrm{bc}$ \\
$23-E-6$ & $10^{7}$ & $100 \mathrm{a}$ & $12 \mathrm{~b}$ & $-12 \mathrm{bc}$ \\
& $10^{8}$ & $1 \mathrm{~b}$ & $1 \mathrm{~b}$ & $-10 \mathrm{bc}$ \\
BI-54 & $10^{7}$ & $-3 \mathrm{~b}$ & $-12 \mathrm{~b}$ & $-19 \mathrm{c}$ \\
& &
\end{tabular}

y Treated fruit were incubated at $20^{\circ} \mathrm{C}$ and $95 \%$ relative humidity for 7 days, then incubated at $20^{\circ} \mathrm{C}$ and 50\% RH for 6 days. The control of brown rot by biological agent was calculated as the difference in disease severity between untreated and treated fruit divided by the severity of untreated fruit.

${ }^{\mathrm{z}}$ Numbers followed by the same letter within a column did not differ significantly according to Duncan's multiple range test $(P=0.01)$.
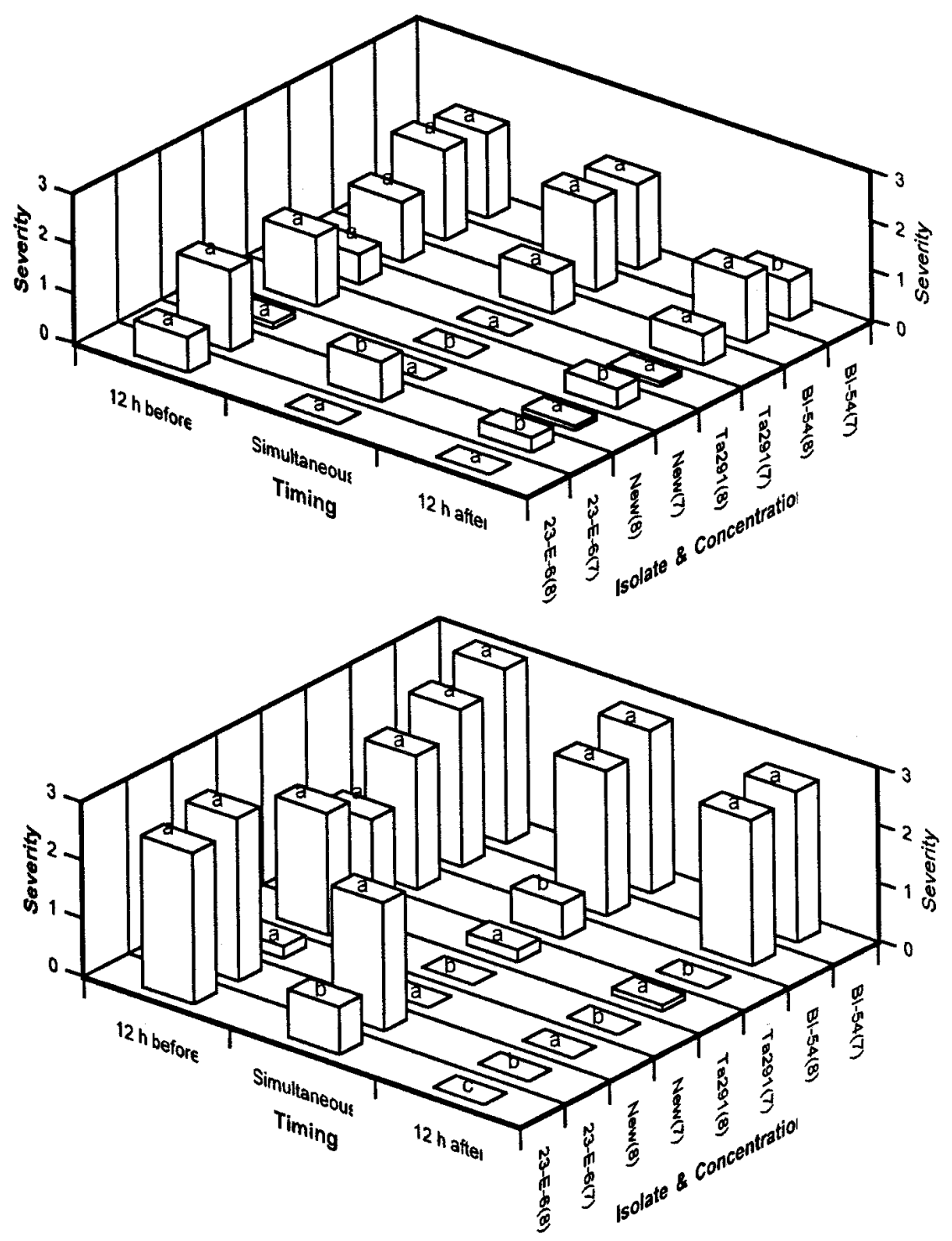

Fig. 6. Effects of biological agent and concentration on brown rot between wounded plum (cv. Casselman) fruit inoculated with $20 \mu \mathrm{l}$ of a suspension containing $1 \times 10^{3}$ (top) and $4 \times 10^{4}$ spores (bottom) of Monilinia fructicola per $\mathrm{ml} 12 \mathrm{~h}$ earlier or $12 \mathrm{~h}$ later than the application of $20 \mu \mathrm{l}$ of the biological control agent or at the same time. Fruit were incubated at $20^{\circ} \mathrm{C}$ and $95 \%$ relative humidity (RH) for $24 \mathrm{~h}$, then at $20^{\circ} \mathrm{C}$ and $50 \% \mathrm{RH}$ for 6 days (top), and incubated at $20^{\circ} \mathrm{C}$ and $95 \% \mathrm{RH}$ for 7 days (bottom). Number in parentheses following the isolate name represents the concentration, e.g., BI-54(7) denotes that BI-54 was applied at $10^{7}$ spores per ml. Mean columns of the same isolate and concentration topped with different letters differed significantly according to Fisher's least significant difference $(P=0.05)$. 
cance of wounds as entry points for $M$. fructicola to initiate infection increased as the spore load on the fruit surface decreased, particularly from $\leq 5$ spores per $\mathrm{mm}^{2}$ for nectarines and $\leq 50$ spores per $\mathrm{mm}^{2}$ for peaches. In orchards, spore load of $M$. fructicola on fruit surface builds up as the season progresses $(15,16)$ and can be extremely high at the end of the season $(20,36)$. For example, an average of 0.22 to $1.7 \times 10^{5}$ spores per fruit were detected by spreading washings from California fruit on plates of selective medium (36). A higher spore load of 0.3 to $2.33 \times 10^{6}$ infective units per peach fruit was monitored in Canberra, Australia (20). If we suppose that the surface area of a stone fruit is 200 $\mathrm{cm}^{2}$, the above numbers are equivalent to a spore load of 1 to 116 infective units per $\mathrm{mm}^{2}$ of fruit surface. Therefore, any measures taken to reduce injury to fruits during picking and packing processes would greatly reduce postharvest brown rot of stone fruits, particularly in years when preharvest brown rot is not severe or spore load is low.

The infection efficiency of $M$. fructicola (isolate 5-E-3) was 0.13 on nectarines and 0.15 on peaches in our tests (Table 1). Higher infection efficiencies were observed on wounded fruits of 0.5 for both nectarines and peaches and of 0.27 on plums (Table 1). These infection efficiencies are extremely high when compared with that (0.09) of Uromyces appendiculatus on Phaseolus vulgaris, a model system of one spore-one infection provided initially by Schein in 1964 (41) and represented by Zadoks and Schein in their pioneering work (49). The lowest spore load used in this study was two spores per wound or fruit; therefore the actual infec-

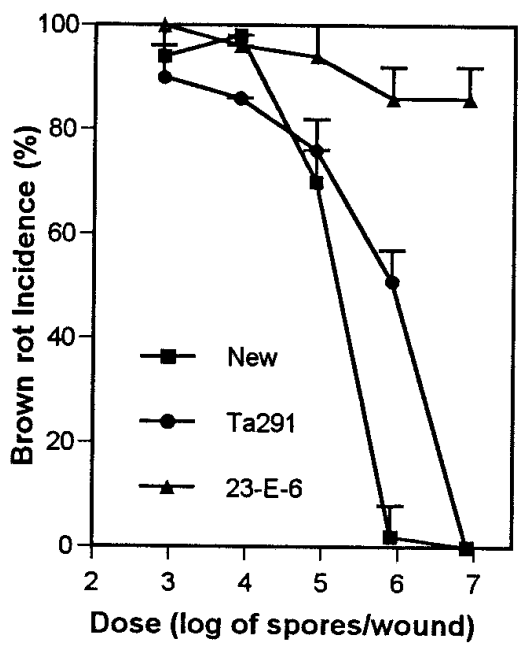

Fig. 7. Influence of dose of biological control agent on brown rot incidence on wounded plum (cv. Casselman) fruit inoculated with $20 \mu \mathrm{l}$ of a suspension containing $8 \times 10^{4}$ spores of Monilinia fructicola per $\mathrm{ml}$ immediately after the application of biological control agent and incubated at $20^{\circ} \mathrm{C}$ and $95 \%$ relative humidity for 7 days. tion efficiency may be even higher than 0.5 on wounded nectarine and peach fruits under conditions similar to ours. This finding that M. fructicola has an extremely high infection efficiency, in combination with large spore loads on fruit surfaces $(20,36)$, can help in explaining the explosive outbreaks of brown rot in orchards at the end of the season during wet years and severe decay (commonly $>50 \%$ ) of fruits during storage and transport to markets (44).

Many biological agents have been investigated for their potential to control brown rot of stone fruits $(19,38)$. Aureobasidium pullulans, Epicoccum purpurascens, and Gliocladium roseum were tested for controlling blossom blight and latent infections of sweet cherry by $M$. fructicola in Oregon (48). Penicillium frequentans, $P$. purpurogenum, and Epicoccum nigrum were investigated for control of twig blight of peach by $M$. laxa in Spain (4-6,2224,28-31). Bacillus subtilis (B-3) was demonstrated to effectively control decay of peach in commercial packing lines $(39,40)$, and Pseudomonas corrugata and $P$. cepacia were demonstrated to control the decay of nectarine and peach fruits at postharvest (44) and processing stages (3). For the first time, this study identified three isolates of Trichoderma spp. for their potential to control postharvest brown rot of stone fruits. Our tests indicate that Trichoderma spp. possess great potential for controlling postharvest brown rot of stone fruits. The Trichoderma isolates tested reduced brown rot by 63 to $98 \%$ on peaches and by 67 to $100 \%$ on plums. In general, control of brown rot increased as the concentration of Trichoderma conidial suspensions increased, which can be described by the models proposed by Johnson (21) and Montesinos and Bonaterra (33).

Interactions among fruit, Trichoderma isolate, and concentration of biological agent were observed with regard to the degree of decay control. At $10^{8}$ spores per $\mathrm{ml}$, isolate New completely suppressed decay on plums $(100 \%)$ but only by $75 \%$ on peaches. In contrast, isolate Ta291 provided a better control of decay on peaches (98\%) than on plums (89\%). However, isolate 23-E-6 exhibited about the same degree of decay control on peaches (63 to $87 \%$ ) as on plums (67 to $85 \%$ ).

We observed that Trichoderma isolates not only reduced infections but also greatly suppressed the sporulation of $M$. fructicola on infected plum fruit. It was obvious that M. fructicola sporulated in smaller areas and in a much more sparse fashion on plums treated with Trichoderma than on control plums. Suppression of sporulation is an important positive aspect of controlling plant disease and is rarely accomplished by biological control agents (12). This implies that the Trichoderma isolates could also suppress secondary infections, and consequently they are important for the postharvest control of brown rot. The bio- chemical mechanism by which brown rot was controlled by these isolates is currently under investigation.

At a concentration of $10^{8}$ spores per $\mathrm{ml}$, the yeast isolate BI-54 reduced decay of Fairtime peaches by $100 \%$ and decay of Casselman plums by $41 \%$. Variations were observed with respect to decay control efficacy between tests and between different cultivars of peaches. Less control of decay was observed on Elegant Lady peaches, and variation among tests with this peach cultivar was noted (Fig. 3). This yeast isolate is being further tested.

Wounding, inoculum density, and biological control agents tested affected not only the infection of stone fruits by $M$. fructicola, but also the incubation period of brown rot. The time required for the development of brown rot symptoms was 1 to 2 days less on wounded than on unwounded fruits at all concentrations of the pathogen (Fig. 1). The incubation period decreased as the concentration of $M$. fructicola increased on both wounded and unwounded fruits (Fig. 1); similar data were obtained with brown rot of detached cherries (34) and dark leaf and pod spot of oilseed rape by Alternaria brassicae (14). The isolates of Trichoderma and a yeast tested all increased the incubation period by delaying the development of brown rot symptoms.

\section{ACKNOWLEDGMENTS}

This study was supported in part by the California Department of Pesticide Regulation, the University of California Statewide Integrated Pest Management Project, the California Tree Fruit Agreement, and the California Prune Board. We thank J. L. Smilanick for providing the yeast isolate and sharing his collection of reference papers, and for helpful discussions about the biological control of brown rot of stone fruits. We thank D. P. Morgan and D. Felts for assistance in harvesting plums and N. Evans for comments on the manuscript.

\section{LITERATURE CITED}

1. Adaskaveg, J. E., and Michailides, T. J. 1996. Cancellation of postharvest use of Rovral 50WP on stone fruit crops and other label changes of the fungicide. Cent. Valley Postharvest Newsl. 5:9-10.

2. Biggs, A. R., El-Kholi, M. M., El-Neshawy, S., and Nickerson, R. 1997. Effects of calcium salts on growth, polygalacturonase activity, and infection of peach fruit by Monilinia fructicola. Plant Dis. 81:399-403.

3. Bosch, J. R., Gonzalez, A. R., Mitchell, J. K. and Aselage, J. M. 1992. Quality changes in peach puree by brown rot (Monilinia fructicola) and biological control agents. J. Food Qual. 15:449-458.

4. De Cal, A., and Melgarejo, P. 1992. Interactions of pesticides and mycoflora of peach twigs. Mycol. Res. 96:1105-1113.

5. De Cal, A., Sagasta, E. M., and Melgarejo, P. 1988. Antifungal substances produced by Penicillium frequentans and their relationship to the biocontrol of Monilinia laxa. Phytopathology 78:888-893.

6. De Cal, A., Sagasta, E. M., and Melgarejo, P. 1990. Biological control of peach twig blight (Monilinia laxa) with Penicillium frequentans. Plant Pathol. 39:612-618.

7. De Vries-Paterson, R. M., Jones, A. L., and Cameron, A. C. 1991. Fungistatic effects of carbon dioxide in a package environment on 
the decay of Michigan sweet cherries by Monilinia fructicola. Plant Dis. 75:943-946.

8. Elad, Y. 1994. Biological control of grape grey mold by Trichoderma harzianum. Crop Prot. 13:35-38

9. El Ghaouth, A., Wilson, C. L., and Wisniewski, M. E. 1995. Sugar analogs as potential fungicides for postharvest pathogens of apple and peach. Plant Dis. 79:254-258.

10. Falconi, C. J., and Mendgen, K. 1994. Epiphytic fungi on apple leaves and their value for control of the postharvest pathogens Botrytis cinerea, Monilinia fructigena and Penicillium expansum. J. Plant Dis. Prot. 101:38-47.

11. Feliciano, A., Feliciano, A. J., Vendrusculo, J., Adaskaveg, J. E., and Ogawa, J. M. 1992. Efficacy of ethanol in postharvest benomylDCNA treatments for control of brown rot of peach. Plant Dis. 76:226-229.

12. Fokkema, N. J. 1996. Biological control of fungal plant diseases. Entomophaga 41:333342 .

13. Gueldner, R. C., Reilly, C. C., Pusey, P. L., Costello, C. E., Arrendale, R. F., Cox, R. H., Himmelsbach, D. S., Crumley, F. G., and Cutler, H. G. 1988. Isolation and identification of iturins as antifungal peptides in biological control of peach brown rot with $\mathrm{Ba}$ cillus subtilis. J. Agric. Food Chem. 36:366370.

14. Hong, C. X., and Fitt, B. D. L. 1996. Factors affecting the incubation period of dark leaf and pod spot (Alternaria brassicae) on oilseed rape (Brassica napus). Eur. J. Plant Pathol. 102:545-553.

15. Hong, C. X., Holtz, B. A., Morgan, D. P., and Michailides, T. J. 1997. Significance of thinned fruit as a source of the secondary inoculum of Monilinia fructicola in California nectarine orchards. Plant Dis. 81:519-524.

16. Hong, C. X., and Michailides, T. J. 1998. Effect of temperature on the discharge and germination of ascospores by apothecia of Monilinia fructicola. Plant Dis. 82:195-202.

17. Hong, C. X., Michailides, T. J., and Holtz, B. A. 1996. Resident fungi of stone fruits mummified by Monilinia fructicola. Phytopathology $86:$ S 81 .

18. Horvat, R. J., Chapman, G. W., Jr., Robertson, J. A., Meredith, F. I., Scorza, R., Callahan, A. M., and Morgens, P. 1990. Comparison of the volatile compounds from several commercial peach cultivars. J. Agric. Food Chem. 38:234237.

19. Janisiewicz, W. J., and Bors, B. 1995. Development of a microbial community of bacterial and yeast antagonists to control wound-invading postharvest pathogens of fruits. Appl. Environ. Microbiol. 61:3261-3267.

20. Jerome, S. M. R. 1958. Brown rot of stone fruits: Latent contamination in relation to spread of the disease. J. Aust. Inst. Agric. Sci. 24:132-140.

21. Johnson, K. B. 1994. Dose-response relationships and inundative biological control. Phy- topathology 84:780-784.

22. Larena, I., and Melgarejo, P. 1993. The lytic enzymatic complex of Penicillium purpurogenum and its effects on Monilinia laxa. Mycol. Res. 97:105-110

23. Madrigal, C., Tadeo, J. L., and Melgarejo, P. 1991. Relationship between flavipin production by Epicoccum nigrum and antagonism against Monilinia laxa. Mycol. Res. 95:13751381.

24. Madrigal, C., Tadeo, J. L., and Melgarejo, P. 1993. Degradation of flavipin by Monilinia laxa. Mycol. Res. 97:634-636.

25. Margosan, D. A., Smilanick, J. L., Simmons, G. F., and Henson, D. J. 1997. Combination of hot water and ethanol to control postharvest decay of peaches and nectarines. Plant Dis. 81:1405-1409.

26. Mckeen, C. D., Reilly, C. C., and Pusey, P. L. 1986. Production and partial characterization of antifungal substances antagonistic to Monilinia fructicola from Bacillus subtilis. Phytopathology 76:136-139.

27. McLaughlin, R. L., Wilson, C. L., Droby, S., Ben-Arie, R., and Chalutz, E. 1992. Biological control of postharvest diseases of grape, peach, and apple with the yeasts Kloeckera apiculata and Candida guilliermondii. Plant Dis. 76:470-473.

28. Melgarejo, P., Carrillo, R., and Sagasta, E. M. 1985. Mycoflora of peach twigs and flowers and its possible significance in biocontrol of Monilinia laxa. Trans. Br. Mycol. Soc. 85:313-317.

29. Melgarejo, P., Carrillo, R., and Sagasta, E. M. 1986. Potential for biological control of Monilinia laxa in peach twigs. Crop Prot. 5:422-426.

30. Melgarejo, P., De Cal, A., and Sagasta, E. M. 1989. Influence of Penicillium frequentans and two of its antibiotics on production of stromata by Monilinia laxa in culture. Can. J. Bot. 67:83-87.

31. Melgarejo, P., and Sagasta, E. M. 1986. Destructive morphological changes induced in Monilinia laxa by Penicillium purpurogenum. Trans. Br. Mycol. Soc. 86:343-346.

32. Michailides, T. J., and Morgan, D. P. 1997. Influence of fruit-to-fruit contact on the susceptibility of French prune to infection by Monilinia fructicola. Plant Dis. 81:14161424.

33. Montesinos, E., and Bonaterra, A. 1996. Dose-response models in biological control of plant pathogens: An empirical verification. Phytopathology 86:464-472.

34. Northover, J., and Biggs, A. R. 1995. Effect of conidial concentration of Monilinia fructicola on brown rot development in detached cherries. Can. J. Plant Pathol. 17:205-214.

35. O'Neill, T. M., Niv, A., Elad, Y., and Shtienberg, D. 1996. Biological control of Botrytis cinerea on tomato stem wounds with Trichoderma harzianum. Eur. J. Plant Pathol.
102:635-643.

36. Phillips, D. J. 1971. A medium for the selective growth of Monilinia species. Phytopathology 61:906.

37. Poulos, P. L., and Heuberger, J. W. 1952. Relation of wounds to the fruit rot phase of the brown rot disease of peaches. Plant Dis. Rep. 36:198-200.

38. Pratella, G. C., Mari, M., Guizzardi, M., and Folchi, A. 1993. Preliminary studies on the efficiency of endophytes in the biological control of the postharvest pathogens Monilinia laxa and Rhizopus stolonifer in stone fruit. Postharvest Biol. Technol. 3:361368.

39. Pusey, P. L., Hotchkiss, M. W., Dulmage, H. T., Baumgardner, R. A., Zehr, E. I., Reilly, C. C., and Wilson, C. L. 1988. Pilot tests for commercial production and application of $\mathrm{Ba}$ cillus subtilis (B-3) for postharvest control of peach brown rot. Plant Dis. 72:622-626.

40. Pusey, P. L., Wilson, C. L., Hotchkiss, M. W., and Franklin, J. D. 1986. Compatibility of Bacillus subtilis for postharvest control of peach brown rot with commercial fruit waxes, dichloran, and cold-storage conditions. Plant Dis. 70:587-590.

41. Schein, R. D. 1964. Design, performance, and use of a quantitative inoculator. Phytopathology 54:509-513.

42. Sholberg, P. L., and Gaunce, A. P. 1996. Fumigation of stone fruit with acetic acid to control postharvest decay. Crop Prot. 15:681686.

43. Smilanick, J. L. 1994. Strategies for the isolation and testing of biocontrol agents. Pages 25-41 in: Biological Control of Postharvest Diseases Theory and Practice. C. L. Wilson and M. E. Wisniewski, eds. CRC Press, London.

44. Smilanick, J. L., Denis-Arrue, R., Bosch, J. R., Gonzalez, A. R., Henson, D., and Janisiewicz, W. J. 1993. Control of postharvest brown rot of nectarines and peaches by $\mathrm{Pseu}$ domonas species. Crop Prot. 12:513-520.

45. Stevens, C., Wilson, C. L., Lu, J. Y., Khan, V. A., Chalutz, E., Droby, S., Kabwe, M. K. Haung, Z., Adeyeye, O., and Pusey, L. P. 1996. Plant hormesis induced by ultraviolet light-C for controlling postharvest diseases of tree fruits. Crop Prot. 15:129-134

46. Valleau, W. D. 1915. Varietal resistance of plums to brown rot. J. Agric. Res. 5:365-396.

47. Wade, G. C. 1956. Investigations on the brown rot of apricots caused by Sclerotinia fructicola (Wint.) Rehm.: The occurrence of latent infection in fruit. Aust. J. Agric. Res. 7:504-516.

48. Wittig, H. P. P., Johnson, K. B., and Pscheidt, J. W. 1997. Effect of epiphytic fungi on brown rot blossom blight and latent infections in sweet cherry. Plant Dis. 81:383-387.

49. Zadoks, J. C., and Schein, R. D. 1979. Epidemiology and Plant Disease Management. Oxford University Press, New York. 